\title{
Does The Vehicle Type Affect the Persistence of Calcium Hydroxide When Removing with Sonic Activation?
}

\author{
Sevinç Aktemur Türker(0000-0001-8740-2480) ${ }^{\alpha}$, Fatma Zühal Yurdagül(0000-0002-1119-4969) ${ }^{\alpha}$, \\ Sena Kaşıkçı (0000-0003-4270-9467) ${ }^{\alpha}$
}

Selcuk Dent J, 2021; 8: 699-702 (Doi: 10.15311/selcukdentj.777379)

Başvuru Tarihi: 06 Ağustos 2020 Yayına Kabul Tarihi: 09 Haziran 2021

\section{ABSTRACT}

Does The Vehicle Type Affect the Persistence of Calcium Hydroxide When Removing with Sonic Activation?

Background: This in vitro study aimed to evaluate the persistence of calcium hydroxide $(\mathrm{CH})$ associated with different vehicles on the artificial cavities after removing with sonic activation or conventional needle irrigation (CNI).

Methods: Seventy-two extracted single-rooted teeth were instrumented with ProTaper Universal rotary system up to F4. The roots were split longitudinally, and standardized cavities were prepared. The roots were assigned into 3 groups $(n=24)$, according to vehicles used; distilled water, glycerin, and propylene glycol. In each group, cavities were filled with $\mathrm{CH}$ mixed with the respective vehicle. After reassembly, the removal of $\mathrm{CH}$ dressing was performed with either sonic activation (EDDY) or $\mathrm{CNI}(n=12)$. The remnants of $\mathrm{CH}$ were assessed under a microscope at $\times 40$ magnification. A four-grade scoring system was used to evaluate. Kruskal-Wallis and Mann-Whitney U-tests were used to compare the data.

Results: There was a significant difference among groups $(p=0.000)$. Complete removal of $\mathrm{CH}$ was found in the distilled water and propylene glycol groups when EDDY was used. EDDY was significantly more effective than $\mathrm{CNI}$ in the removal of $\mathrm{CH}$ mixed with distilled water and propylene glycol $p=0.001$ and $p=0,002$, respectively. Whereas no significant difference was found between EDDY and $\mathrm{CNI}$ in the glycerin group $(p=0.219)$. The lowest $\mathrm{CH}$ remnants were found in the distilled water group when $\mathrm{CNI}$ was used.

Conclusion: The vehicle associated with $\mathrm{CH}$ and irrigation activation is important for its retrieval. EDDY provided the complete removal of $\mathrm{CH}$ when mixed with distilled water or propylene glycol.

\section{KEYWORDS}

Calcium hydroxide removal, EDDY, Vehicle type

Calcium hydroxide $(\mathrm{CH})$ has been commonly used as an interappointment paste because of its antimicrobial activity ${ }^{1}$, effectiveness on neutralization of bacterial endotoxin ${ }^{2}$ and stimulate periapical healing. ${ }^{3}$ However, $\mathrm{CH}$ has some limitations. It has been reported that the sealing ability of root canal sealers can be affected by the remnants of $\mathrm{CH}^{4-6}$ Therefore, $\mathrm{CH}$ should be removed completely before the permanent root canal filling. Due to the manual irrigation with a syringe is unable to remove $\mathrm{CH}$ completely, irrigation activation

\section{öz}

Taşıyıcı Tipi Sonik Aktivasyon Ile Uzaklaştırıldığında Kalsiyum Hidroksitin Kök Kanal Duvarlarındaki Devamlıı̆̆ını Etkiler Mi?

Amaç: $\mathrm{Bu}$ in vitro çalışma farklı taşıyıcılarla ilişkili kalsiyum hidroksitin $(\mathrm{KH})$ yapay olarak oluşturulmuş kavitelerden sonik aktivasyon veya geleneksel iğne irrigasyonu (Gii) kullanılarak uzaklaştırımasından sonra devamlıığını değerlendirmeyi amaçlamaktadır.

Gereç ve Yöntemler: 72 adet çekilmiş tek köklü dişler ProTape Universal döner eğe sistemi ile F4'e kadar genişletildi. Dişler uzunlamasına kesilerek standart kaviteler açıldı. Kullanılan taşıyıcı tipine göre kökler 3 gruba ayrıldı $(n=24)$; distile su, gliserin ve propilen glikol. Her bir grupta, kaviteler bu taşıyıcılardan biriyle karıştırılan kalsiyum hidroksitle dolduruldu. Kök parçalarının tekrar birleştirilmesinden sonra kalsiyum hidroksitin uzaklaştıııması ya sonik aktivasyon (EDDY) ya da Gii ile yapıldı $(n=12)$. Kalan $\mathrm{KH}$ artıkları bir mikroskop kullanılarak $\times 40$ büyuitme ile degerlendirildi. Değerlendirme için 4-skorlu skala kullanıldı. Kruskal-Wallis, Mann-Whitney $\mathrm{U}$ testleri verileri karşılaştırmak için kullanıldı.

Bulgular: Gruplar arasında anlamlı fark bulundu $(p=0.000)$. EDDY kullanıldığında, distile su ve propilen glikol ile karıştıılan KH'in tamamen uzaklaştırıldığı bulundu. EDDY, distile su ve propilen glikol ile karıștırılan KH'i uzaklaștırmada, Gil'den daha etkili bulundu $p=0.001$ ve $p=0,002$, sırasıly. Fakat gliserin ile karıştırılan KH'i uzaklaștırmada EDDY ve Gii arasında fark bulunmadı $(p=0.219)$. Gil kullanıldığında kalan $\mathrm{KH}$ artıkları en az distile su grubunda bulundu.

Sonuç: $\mathrm{KH}$ ile ilişkili taşıyıcı tipi ve yıkama solusyonunun aktivasyonu uzaklaştırımasında önemlidir. EDDY distile su veya propilen glikol ile karıştıılan KH'in tamamen uzaklaştııımasın sağlamıştır.

\section{ANAHTAR KELIMELER}

Kalsiyum hidroksitin uzaklaştırılması, EDDY, Taşıyıcı tipi

with combination of chemical agents has been suggested to ensure favorable results. ${ }^{7}$ Recently, EDDY (VDW, Munich, Germany) has been introduced for irrigant activation. It is a polyamide polymer tip with a size 25 and .04 taper. According to manufacturer's instructions, EDDY tips are powered at a high frequency of up to $6000 \mathrm{~Hz}$ by air scaler. It is also stated that with vibration of 5000 to $6000 \mathrm{~Hz}$, EDDY creates a threedimensional movement. EDDY has been reported as an effective irrigation activation method in the removal of

\footnotetext{
${ }^{\alpha}$ Zonguldak Builent Ecevit University Faculty of Dentistry, Department of Endodontics, Zonguldak, Turkey.
} 


\section{$\mathrm{CH}^{7,8}$}

$\mathrm{CH}$ can be mixed with either an aqueous or a viscous solution to facilitate its insertion into to root canal and to improve its biological or microbiological properties. ${ }^{9}$ Aqueous solutions are the most commonly used carriers promoting high solubility and rapid ion dissociates. On the other hand, a viscous vehicle, due to its high molecular weight the dissociation of $\mathrm{CH}$ become slower. ${ }^{10}$ Propylene glycol has been used as a viscous vehicle and provides the slow release of calcium and hydroxyl ions. ${ }^{11}$ Glycerin is another viscous colorless and hygroscopic vehicle that facilitates placement of $\mathrm{CH}$ in the root canals. ${ }^{12}$

Several studies with different irrigants and techniques investigated the removal of $\mathrm{CH}$ from root canal systems. $^{7,8,13-16}$ In some of these studies, authors used $\begin{array}{lll}\text { aqueous } & \mathrm{CH} & \text { suspensions }{ }^{7}, \quad \text { viscous }\end{array}$ suspensions $8,13,15,16$, and some did not report the vehicle type. ${ }^{14}$ To the authors' knowledge, little is known about the effect of the aqueous and viscous vehicles on the $\mathrm{CH}$ persistence on the root canal walls after removing with sonic activation. Therefore, the presence of remnants of $\mathrm{CH}$ mixed with distilled water, propylene glycol, or glycerin on dentin walls after removal with EDDY or conventional needle irrigation was evaluated in this study. The null hypothesis tested was there would be no difference between different vehicles and irrigation techniques.

\section{MATERIALS AND METHODS}

Seventy-two extracted straight and single-rooted mandibular premolars with a single root canal and intact root tips were used for this in vitro study after the university non-interventional clinical research ethics board approval (protocol no: 2020/13-7). The crowns were removed to standardize the length of the roots.17 A $18 \mathrm{~mm}$ standardized root length and a $17 \mathrm{~mm}$ working length (WL) was obtained for each specimen. The root canals were instrumented using the ProTaper Universal rotary system (Dentsply Maillefer; Ballagiues, Switzerland) up to size 40 (F4) using an endodontic motor (X-Smart: Dentsply Maillefer; Ballagiues, Switzerland) with the settings according to the manufacturer's instructions. During instrumentation, irrigation was delivered via a 30-gauge side-vented irrigation needle (Max-i Probe: Dentsply Maillefer North America). $2 \mathrm{~mL} 2.5 \% \mathrm{NaOCl}$ (sodium hypochlorite) was used after each file changes. $5 \mathrm{~mL}$ EDTA $17 \%$ and $10-\mathrm{mL}$ distilled water were used for the final irrigation.

Longitudinally grooves were prepared on the buccal and lingual root surfaces after root canal preparation completed. Roots split into two halves along their buccolingual long axis with a hammer and a chisel. A standard cavity of $3 \mathrm{~mm}$ in length, $1 \mathrm{~mm}$ in width and $0.5 \mathrm{~mm}$ in depth was prepared in one root segment, 2$3 \mathrm{~mm}$ from the apex using a diamond bur. Three groups were assigned according to the vehicle used ( $\mathrm{n}$ =24): Group distilled water: $\mathrm{CH}$ mixed with distilled water; Group glycerin: $\mathrm{CH}$ mixed with glycerin; and Group 3: propylene glycol $\mathrm{CH}$ mixed with propylene glycol. All medicaments used were mixed to a creamy consistency on a glass slab using $\mathrm{CH}$ powder and the respective solution. Each cavity was filled with $\mathrm{CH}$ paste mixed with the respective vehicles using paper points. Roots were reassembled with wax and the apical foramen was covered with wax to simulate a closed system. 7 After 1 week at $37^{\circ} \mathrm{C}$ of storage, in each group calcium hydroxide was removed with EDDY or conventional needle irrigation (CNI) as follows $(n=12)$ :

Conventional needle irrigation (CNI): A 30-gauge irrigation needle (Max-i Probe) placed $1 \mathrm{~mm}$ short of the WL. Root canals were irrigated with a total of $6 \mathrm{~mL}$ $5 \% \mathrm{NaOCl}, 2 \mathrm{~mL}$ of $17 \%$ EDTA and a final wash with 5 $\mathrm{mL}$ of distilled water.

EDDY: EDDY (\#25, 0.04) was used with a handpiece (SonicFlex 2003 L; Kavo, Biberach, Germany) in the root canal $1 \mathrm{~mm}$ short from the WL. Agitation of $2 \mathrm{~mL}$ of $5 \% \mathrm{NaOCl}$ was performed with EDDY for $20 \mathrm{~s}$ and repeated twice more. Subsequently, $2 \mathrm{~mL}$ of $17 \%$ EDTA was agitated for $20 \mathrm{~s}$ with EDDY. Then, root canals irrigated with $5 \mathrm{~mL}$ of distilled water.

The root halves were separated again to detect the $\mathrm{CH}$ remnants. Photographs of each cavity were saved as tagged image file using a stereomicroscope (Leica M320 F12, Heerbrugg, Schweiz) at $\times 40$ magnification. The amount of calcium hydroxide remaining in the grooves was independently scored by 2 calibrated and blinded operators according to the four-grade scoring system17: score 0 , the groove is empty; score 1, $<50 \%$ of the groove is filled with $\mathrm{CH}$; score $2,>50 \%$ of the groove is filled with $\mathrm{CH}$; score $3,100 \%$ of the groove is filled with $\mathrm{CH}$ (Figure 1).

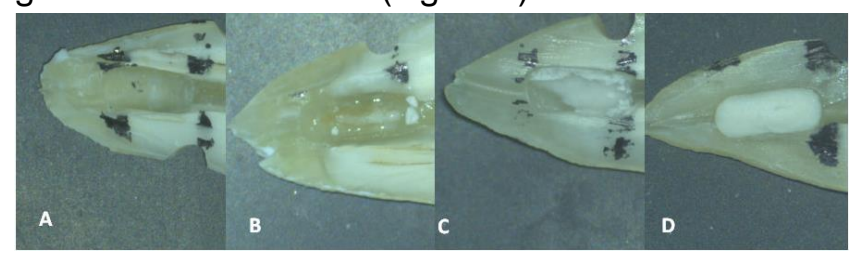

Figure 1

Representative images for four-grade scoring system. A) score 0 ; the groove is empty B) score 1; less than half of the groove is filled C) score 2; more than half of the groove is filled D) score 3; the groove is filled completely $(\times 40)$

Differences were analyzed using the Kruskal-Wallis and Mann-Whitney tests with Bonferroni correction 
$(p=0.05)$

\section{RESULTS}

Table 1 shows the results. There was a significant difference among groups $(p=0.000)$. The lowest $\mathrm{CH}$ remnants were found in the distilled water group when $\mathrm{CNI}$ was used. Complete removal of $\mathrm{CH}$ was found in the distilled water and propylene glycol groups when EDDY was used. EDDY was significantly more effective than $\mathrm{CNI}$ in the removal of $\mathrm{CH}$ in distilled water and propylene glycol groups $(p=0,001$ and $p=0,002$, respectively). Whereas no significant difference was found between EDDY and $\mathrm{CNI}$ in the glycerin group $(p=0,219)$.

\section{Table 1.}

\section{The Scoring Results of the Artificial Cavities}

\begin{tabular}{|ccccc|}
\hline \multirow{2}{*}{ Groups } & & & & \\
\hline \multirow{2}{*}{ Distilled water } & CNI & $1.0^{\mathrm{a}}$ & 0 & 3 \\
\cline { 2 - 5 } & EDDY & $.00^{\mathrm{b}}$ & 0 & 0 \\
\hline \multirow{2}{*}{ Glycerin } & $\mathrm{CNI}$ & $3.0^{\mathrm{c}}$ & 2 & 3 \\
\hline \multirow{2}{*}{ Propylene Glycol } & EDDY & $2.0^{\mathrm{c}}$ & 1 & 3 \\
\hline & CNI & $3.0^{\mathrm{dc}}$ & 0 & 3 \\
\hline
\end{tabular}

Values with different superscript letters were statistically different at $P=.05$

\section{DISCUSSION}

This in vitro study was conducted to evaluate the persistence of an aqueous and two viscous suspensions of $\mathrm{CH}$ on the artificial cavities after removing with EDDY or CNI. Root canals were prepared up to size 40/.06. Therefore, enough space for EDDY activation (tip size 25 and .04 taper) was provided. Cavities were simulated in the apical third of the roots by using diamond burs to obtain standardization. A combination of $\mathrm{NaOCl}$ and EDTA was used for removing $\mathrm{CH}$ during the irrigation process with the same volume and irrigation times for both groups.

The present results revealed that there was a significant difference among groups. Therefore, the null hypothesis tested was rejected. The lowest $\mathrm{CH}$ remnants were found in the distilled water group when $\mathrm{CNI}$ was used. The results of this study were similar to those of previous studies. ${ }^{18,19}$ Nandini et al. ${ }^{18}$ reported that $\mathrm{CH}$ mixed with silicone oil and iodoform was more challenging to remove than $\mathrm{CH}$ mixed with distilled water. Similarly, Lambrianidis et al.19 demonstrated significantly more $\mathrm{CH}$ remnants when mixed with methylcellulose compared to distilled water. On the contrary, Balvedi et al. ${ }^{20}$ did not demostrated a significant difference among saline, polyethylene glycol, and polyethylene glycol camphorated paramonochlorophenol when used passive ultrasonic irrigation or manual irrigation.

Furthermore, De Faria-Junior et al. ${ }^{21}$ demonstrated that association of different vehicles with $\mathrm{CH}$ did not affect its persistence. They used silicone oil, $2 \%$ chlorhexidine gluconate, and propylene glycol in their study. The differences between these results may be attributed to the different methodologies and types of vehicles used. In that study, researchers solely used $\mathrm{NaOCl}$ without any activation during the $\mathrm{CH}$ removing process. However, in the present study $\mathrm{NaOCl}$ and EDTA with sonic activation was used.

According to the present results, sonic activation with EDDY was more effective than $\mathrm{CNI}$ when $\mathrm{CH}$ mixed with distilled water or propylene glycol. However, this difference was not observed in the glycerin group. $\mathrm{CH}$ with glycerin demonstrated significantly higher retention capacity than $\mathrm{CH}$ mixed with distilled water and propylene glycol when EDDY was used. Glycerin resisted dissolution and was retained in the cavity even though irrigation activation. The removal efficiency of EDDY has been assessed in two previous reports. ${ }^{7,8}$ These studies reported the effectiveness of EDDY in the removal of $\mathrm{CH}$ when compared with manual irrigation. In the study by Donnermeyer et al. ${ }^{7}$ an aqueous $\mathrm{CH}$ paste was prepared and solely used $\mathrm{NaOCl}$. However, Marques-da-Silva et al. ${ }^{8}$ used a viscous suspension and used a combination of $\mathrm{NaOCl}$ and EDTA during the activation process. In those studies, EDDY did not provide complete removal of $\mathrm{CH}$. However, the findings of the present study showed that all cavities in teeth of the distilled water group were removed completely with EDDY. It can be concluded that using both of $\mathrm{NaOCl}$ and EDTA with sonic activation might improve the removal results of $\mathrm{CH}$ mixed with distilled water or propylene glycol.

\section{CONCLUSION}

The findings indicate that the vehicle mixed with calcium hydroxide and activation technique is important for its retrieval. EDDY provided the complete removal of $\mathrm{CH}$ when mixed with distilled water or propylene glycol. Further studies with this association are necessary for better appreciation of the subject. 


\section{REFERENCES}

1. Siqueira JF, Jr., Guimaraes-Pinto T, Rocas IN. Effects of chemomechanical preparation with $2.5 \%$ sodium hypochlorite and intracanal medication with calcium hydroxide on cultivable bacteria in infected root canals. J Endod 2007; 33:800-5.

2. Tanomaru JM, Leonardo MR, Tanomaru Filho M, Bonetti Filho I, Silva LA. Effect of different irrigation solutions and calcium hydroxide on bacterial LPS. Int Endod J 2003; 36:733-9.

3. Leonardo MR, Hernandez ME, Silva LA, TanomaruFilho M. Effect of a calcium hydroxide- based root canal dressing on periapical repair in dogs: a histological study. Oral Surg Oral Med Oral Pathol Oral Radiol Endod 2006; 102:680-5.

4. Calt S, Serper A. Dentinal tubule penetration of root canal sealers after root canal dressing with calcium hydroxide. J Endod 1999; 25:431-3.

5. Kim SK, Kim YO. Influence of calcium hydroxide intracanal medication on apical seal. Int Endod J 2002; 35:623-8.

6. Uzunoglu-Ozyurek E, Erdogan O, Aktemur Turker S. Effect of Calcium Hydroxide Dressing on the Dentinal Tubule Penetration of 2 Different Root Canal Sealers: A Confocal Laser Scanning Microscopic Study. J Endod 2018; 44:1018-23.

7. Donnermeyer D, Wyrsch H, Burklein S, Schafer E. Removal of Calcium Hydroxide from Artificial Grooves in Straight Root Canals: Sonic Activation Using EDDY Versus Passive Ultrasonic Irrigation and XPendo Finisher. J Endod 2019; 45:322-6.

8. Marques-da-Silva B, Alberton CS, Tomazinho FSF, M. C. L. Gabardo, M. A. H. Duarte, R.R.Vivan et al. Effectiveness of five instruments when removing calcium hydroxide paste from simulated internal root resorption cavities inextracted maxillary central incisors. Int Endod J 2020; 53:366-75.

9. Mohammadi Z, Dummer PM. Properties and applications of calcium hydroxide in endodontics and dental traumatology. Int Endod J 2011; 44:697-730.

10. Fava LR, Saunders WP. Calcium hydroxide pastes: classification and clinical indications. Int Endod $\mathrm{J}$ 1999; 32:257-82.

11. Grover C, Shetty N. Evaluation of calcium ion release and change in $\mathrm{pH}$ on combining calcium hydroxide with different vehicles. Contemp Clin Dent 2014; 5:434-9.

12. Rivera EM, Williams K. Placement of calcium hydroxide in simulated canals: comparison of glycerin versus water. J Endod 1994; 20:445-8.

13. de Oliveira RL, Guerisoli DMZ, Duque JA, Murilo P. Alcalde, Hélio K. Onoda, et al. Computed microtomography evaluation of calcium hydroxidebased root canal dressing removal from oval root canals by different methods of irrigation. Microsc Res Tech 2019; 82:232-7.

14. Gokturk H, Ozkocak I, Buyukgebiz F, Demir O. Effectiveness of various irrigation protocols for the removal of calcium hydroxide from artificial standardized grooves. J Appl Oral Sci 2017; 25:290-8.
15. Capar ID, Ozcan E, Arslan H, Ertas H, Aydinbelge HA. Effect of different final irrigation methods on the removal of calcium hydroxide from an artificial standardized groove in the apical third of root canals. J Endod 2014; 40:451-4.

16. Ma JZ, Shen Y, Al-Ashaw AJ, H. Y. Khaleel, Y. Yang, Z. J. Wang et al. Micro-computed tomography evaluation of the removal of calcium hydroxide medicament from C-shaped root canals of mandibular second molars. Int Endod J 2015; 48:333-41.

17.van der Sluis LW, Wu MK, Wesselink PR. The evaluation of removal of calcium hydroxide paste from an artificial standardized groove in the apical root canal using different irrigation methodologies. Int Endod $\mathrm{J}$ 2007; 40:52-7.

18. Nandini S, Velmurugan N, Kandaswamy D. Removal efficiency of calcium hydroxide intracanal medicament with two calcium chelators: volumetric analysis using spiral CT, an in vitro study. J Endod 2006; 32:1097101.

19. Lambrianidis T, Margelos J, Beltes P. Removal efficiency of calcium hydroxide dressing from the root canal. J Endod 1999; 25:85-8.

20. Balvedi RP, Versiani MA, Manna FF, Biffi JC. A comparison of two techniques for the removal of calcium hydroxide from root canals. Int Endod J 2010; 43:763-8.

21. De Faria-Junior NB, Keine KC, So MV, Weckwerth PH, Guerreiro-Tanomaru JM, Kuga MC. Residues of calcium hydroxide-based intracanal medication associated with different vehicles: a scanning electron microscopy evaluation. Microsc Res Tech 2012; 75:898-902.

Corresponding Author:

Sevinç AKTEMUR TÜRKER

Zonguldak Bülent Ecevit University

Faculty of Dentistry

Department of Endodontics

Zonguldak, Turkey

Phone : +90 3722613639

E-mail : sevincaktemur@hotmail.com 